\title{
System Error: Complicity with Surveillance in Contemporary Workplace Documentaries
}

\author{
Annie Ring \\ University College London
}

This article sets itself against the bulk of scholarship on surveillance, which is characterized by emphasis either on Michel Foucault's analysis of the Panopticon, or on Gilles Deleuze's too-brief "Postscript on the Societies of Control." In contrast to these dominant critical paradigms, the article recuperates a mode of governmentality proposed in Foucault's last lectures on "Security," in order to draw out the latent instabilities that beset contemporary surveillance systems and hence reveal the possibility of resisting them. This recuperation of "Security" proceeds by way of close readings of workplace documentaries by radical filmmakers Harun Farocki (Die Schöpfer der Einkaufswelten, Ein neues Produkt, and other films) and Carmen Losmann (Work Hard Play Hard). When analyzed in concert with Foucault's neglected late lectures, and in a final move with the post-Freudian theory of perversion, these films prompt new reflection on complicity with surveillance and, importantly, the potential of that complicity as an error in the systems of contemporary workplaces and leisure-spaces.

Keywords: documentary, Harun Farocki, governmentality, Carmen Losmann, Panopticon, perversion, "Postscript on the Societies of Control" (Gilles Deleuze), psychoanalysis, Security, Territory, Population (Michel Foucault), surveillance

German cinema has generated a number of important aesthetic responses to surveillance in recent years, responses that challenge any view of surveillance as a system of technologies that secure control over their watched subjects. Films made in Germany, in particular since the turn of the millennium, have observed that surveillance is - like any other system — susceptible to failure. This is a susceptibility 
that, as I suggest in the following pages, might yet have some resistant potential in an age when surveillance seems to brook no resistance at all from those who are subject to it. The limits of surveillance by the East German Stasi are evident, for instance, in Florian Henckel von Donnersmarck's German Democratic Republic (GDR)-set blockbuster, Das Leben der Anderen (2007), in which the spy-turned-good Gerhard Wiesler cannot protect the couple over whom he has gradually come to keep a benign watch. They are also present in Christian Petzold's Barbara (2012), a feature film cowritten with radical documentarist Harun Farocki, in which the operations of the Stasi against the eponymous East German doctor prove intrusive but insufficient to prevent one character's escape from the GDR by night-time subterfuge. Eric Rentschler has tracked, meanwhile, the failure of a more contemporary mode of surveillance in Christoph Hochhäusler's Eine Minute Dunkel (Rentschler 639-40), one of a trio of TV crime dramas directed by Petzold and Hochhäusler-two leading names of the progressive Berlin School of filmmaking — and the Berlin-Schoolcritical director Dominik Graf, under the collective title Dreileben (2011). The pivotal plot moment in the Dreileben trilogy is provided by a crime that occurs in the precise moment when a CCTV camera blacks out, an error that enables the crucial image to slip from the surveillance archive. Yet while the failure of surveillance forms a crucial plot feature in those high-profile film dramas, some of the most challenging cinematic engagements with the limits of surveillance are to be found in the experimental documentaries that have emerged in the past fifteen or so years from Germanlanguage film's furthest left wing.

Those experimental documentaries include the works of Harun Farocki (born 1944, Nový Jičín, Czech Republic; died 2014, Berlin) and the award-winning 
German-language documentary of 2011, Work Hard Play Hard by Carmen Losmann (born 1978, Crailsheim). In the works that I will analyze in the following pages, Farocki and Losmann can be seen to reject dramatic plots in favour of precise aesthetic engagement with surveillance systems in order to point up their potentially productive flaws. Importantly, the forms of surveillance that these filmmakers show operating in contemporary German-speaking contexts are not always optical. They do not necessarily take the form of CCTV videography or the gaze of a spy or prison warder upon unwilling "victims" of surveillance. Instead, what these two radical documentarists urge us to admit is that there are a whole set of new forms of surveillance at work in the contemporary West: these include techniques of observation and assessment, prediction and pre-emption, especially in the workplace, in whose execution many workers participate. Speaking about her film, Losmann has described the desire to capture something almost impossible to represent visually, namely the immaterial labour that dominates the white-collar workplace (Losmann in Cambridge, July 2015). Her resulting film project, and the workplace documentaries by Farocki discussed here, are rich in potential both for understanding the operations of surveillance and for imagining possible resistance to it in those visually ungraspable working environments. For curiously, the place where resistance seems most feasible in these films is where we often feel most constrained, namely the places of work in which many of the citizens of late capitalism spend the majority of our waking lives. The critique that Farocki's and Losmann's films level at those processes of observation and manipulation and their way of addressing contemporary problems of complicity in systems of surveillance are not easy to bear. However, if we are willing to pay attention to them as viewers, their works can offer a surprisingly 
optimistic view of the way in which surveillance can never truly secure control. As these films show, the failure of surveillance systems may in fact be found in the instances where those who are being watched, the workers whose passivity keeps systems of surveillance and control functioning, appear to be at their most un-free.

Thus, Harun Farocki’s essay film of 2001, Die Schöpfer der Einkaufswelten, presents a West Germany dominated by visual control, against whose Verhaltenslehren for the contemporary worker-consumer resistance seems futile. Yet in many other of the documentary works of the latter part of Farocki's career, between the end of the Cold War and his death in July 2014, he explored a latent instability in the regimes of surveillance, assessment, and manipulation on which Western capitalism currently relies, namely through the disruptive behaviours of the subject of those regimes. These are behaviours that result at times from conscious decisions to resist, but at others, they seem to emerge from drives or somatic responses to surveillance that have no conscious authorship at all. As will become clear in the final parts of this essay, resistance to surveillance does not have to be conscious to be effective; in fact, the most shattering opposition to surveillance can emerge in scenarios defined by seemingly unquestioning participation. Resistant behaviours are at play, for instance, in one of Farocki's last works, Ein neues Produkt (2012), which screens the planning of flexible workplaces by a German firm known for its attempts to bring creativity and even happiness to the profit-making process. These works track techniques of training, manipulation, and surveillance that, when viewed in the stark light of documentary, combine to suggest a system of inescapable manipulation for the contemporary subject, a subject who is forced, or so it seems, to be complicit with them or lose her or his livelihood. Yet, the scenes that Farocki and his teams filmed 
for Ein neues Produkt, and those shot by Carmen Losmann for Work Hard Play Hard (2011), silently observe the imperatives to perform and produce that dominate current high-flexibility workplaces as they struggle with an in-built threat of failure, a threat that these latter works suggest comes from within the very subject late capitalism so painstakingly sets out to manipulate. The subject of recent German cinema, it seems, can never be entirely subsumed by the controlling gaze of surveillance.

In the first section of this article, I visit the early CCTV documentary, Der Riese (1983) by Michael Klier, a contemporary of Fassbinder's. Der Riese is the Urtext for German filmmakers who wish to take on the slippery task of representing surveillance. Losmann's and Farocki's inheritance from Klier's film reminds us that, while their works should indeed be considered in the light of broader trends in German cinema, the documentary mode chosen by these directors enables them to achieve something that feature film cannot, with its conventions of sound- and imagecapture that are too often oriented towards the production of comprehensible plots. ${ }^{1}$ Crucially, the searing critique that Losmann's and Farocki's works carry out is enhanced by their tendency towards self-awareness, in films that continually reflect on their own use of the moving-image technologies on which both cinema and surveillance rely. For instance, surveillance not only captures images and sound in real time, but it also preserves them in archives that can be consulted in order to categorize and test information. Accordingly, a familiar feature of Farocki's oeuvre is his compilation of archives of found material, including CCTV footage and computer simulations, in combination with new footage filmed by his decades-long collaborator Ingo Kratisch. Another feature of surveillance footage is its silence, with CCTV in its early and most familiar forms either capturing only fuzzy grayscale images with no 
sound at all or images with a soundtrack that is too muffled or fragmented to be decoded by the human ear. Displaying a challenging affinity with the images they are critiquing, Farocki's and Losmann's documentaries are works of Direct Cinema, a style characterized by fly-on-the-wall footage that is presented without voice-over commentary at all. By no means are these films made without careful editorial choices on how best to present the images of surveillance and the "work" it does on the subject experiencing it, and of course, they contain diegetic sound, by means of which viewers are informed about the highly personalized methods of assessment and training to which surveilled workers are subjected. Thus, in fact, through their techniques of image-compilation, citation of surveillance technologies, and deliberate, self-reflexive editing, both filmmakers take an especially active role in relation to their material, in an approach that demonstrates a direct inheritance not only from Klier but also from the essay-films of Jean-Luc Godard, Alexander Kluge, and Chris Marker. This shared inheritance allows both Farocki and Losmann to first set up and then bring home their arguments concerning capitalism's attempts to produce a compliant worker- and consumer-subject who does not, despite those attempts, conform comfortably to that model.

Finally, along with their inheritance from the essay-film, Farocki and Losmann share an active interest in cultural theories, many of which stem from beyond the German-speaking tradition, by thinkers such as Michel Foucault and Gilles Deleuze. The theories of Foucault, Deleuze, and others do not only inform the films discussed in this paper. As I argue here, those theories can themselves be understood more deeply with reference to the moving images that these experimental documentaries offer for responding to surveillance. Hence, in what follows, I explore 
the modes of critique employed in Farocki's and Losmann's documentaries by setting them in the context of two opposing models of surveillance: these are the rigid model of the Panopticon, developed by Jeremy Bentham and analyzed by Michel Foucault in his best-known writings, which are concerned with power as a form of Discipline that produces the behaviour of its subject through carefully honed mechanisms and architectures, and the more flexible model of surveillance that was famously observed by Gilles Deleuze in his "Postscript on the Societies of Control" and by Foucault in his lesser-known, late lectures on Security. Thus, one of my aims in this essay is to recuperate the contribution that Foucault made in his seldom-quoted lectures on the operations of late liberalism, which he delivered at the Collège de France in the very last years of his life and which are invoked anew in the recent workplace documentaries of Farocki and Losmann. I argue here that Farocki's and Losmann's works take the theoretical work carried out by Deleuze, Foucault, and others further, as they demonstrate the importance of complicity in the techniques that Deleuze termed Control and Foucault Security. Therefore, in what follows, I pay close attention to the participation, even the collaboration of the surveilled subject as it is emphasized in these films. By focusing in on the collaboration-or perhaps complicity — of the surveilled subject here, ${ }^{2}$ I aim to uncover the contribution these films can make to discussions of how surveillance shapes behaviour, of the way in which it relies upon the precarious complicity of its subjects, and hence of the potential of critical documentary to inspire future modes of interacting with, and ultimately transforming, systems of surveillance.

\section{Two Theories of Surveillance: The Panopticon and Security}


The most familiar model for conceptualizing surveillance in Western modernity is the Panopticon, Jeremy Bentham's 1785 blueprint for an inspection house in which the possibility of total vision on the part of a warder in a central watchtower encircled by cells ensured good behaviour from inmates at all times. Because inmates could not know when they were under observation, their selfpolicing was guaranteed. Not only a prison design, the Panopticon was adaptable for the architecture of asylums, workhouses, factories and schools, all environments in which surveillance and self-policing could effectively monitor and shape the behaviour of those housed in them. Although the design was implemented in certain locations during his lifetime, notably informing the radial design of the Eastern State Penitentiary in Philadelphia, which was visited in 1842 by a Charles Dickens horrified by his own complicity in such a prison system's existence, ${ }^{3}$ Bentham died frustrated at the perceived failure of his project, by means of which he had hoped to contribute more humanitarian alternatives to the public architectures of his time.

Foucault's analysis of the Panopticon as a system of surveillance in his now iconic work Discipline and Punish —its original title Surveiller et punir giving a more accurate sense of the importance of surveillance to his argument — ensured its survival in the imaginary of surveillance in late twentieth- and early twenty-first-century cultural theory. Yet Foucault's account of the Panopticon underscores a central flaw in its design. He argues that not only the prisoner but also the warder is subject to constant surveillance, so that a system is set up in which nobody is free from observation, the panoptic space instead creating "so many small theatres, in which each actor is constantly visible" (Discipline and Punish 200). It was by analyzing these spaces of modern discipline that Foucault came to the conclusion in the mid- 
1970s that power is "a machine in which everyone is caught, those who exercize power just as much as those over whom it is exercized" (Power/Knowledge 156). The effect of panoptic surveillance, in Foucault's view, was not the ideal humanitarian society free from crime that Bentham envisaged but instead a community fraught with suspicion, in which the freedom of the individual and the security of the group could only be very limited.

Figure 1. Panopticon; or the Inspection-House. Architectural drawing by Willey Reveley (1760-1799). Out of copyright

The failed humanitarian project represented by the Panopticon is recalled in a book-length critical manifesto by respected literary writers and political spokespeople Ilija Trojanow and Juli Zeh. Angriff auf die Freiheit was published in Germany in 2009, when the extent of surveillance by the Merkel government of Federal citizens, despite the apparently tight protections against such surveillance in a constitution shaped by the Stasi past, was becoming clear. As a result, in their book Trojanow and Zeh herald "Das Ende der Freiheit" (Trojanow and Zeh 7): in place of the freedom one might have envisaged at the close of the Cold War, they observe the advent of a postliberal society in which no citizen can feel either free or entirely "sicher" (45). Zeh and Trojanow refer to the irony by which the ubiquitous security techniques and technologies surrounding that citizen at the start of the new millennium do not produce more security but instead increase suspicion among all those affected by them. In this way, Trojanow and Zeh echo Foucault's observations on the Panopticon, as architecture of total surveillance that produced an utter insecurity in relation to which, even for the prison warder who ostensibly embodies disciplinary power, "there is no outside" (Discipline and Punish 301).

There is an alternative surveillance model to that of the Panopticon, however, and one that emerges in recent documentaries focused on surveillance in Germany in 
the late twentieth- and start of the twenty-first century. Michael Klier's Der Riese (1983), which consists entirely of CCTV images, hints at a late-modern surveillance model that diverges from the total vision and resulting inescapability generated by the design of the Panopticon and which is invoked in Zeh and Trojanow's writing on the demise of freedom in the unified Federal Republic. The long takes, indistinct visuals, and near silence of Klier's chosen footage make his eighty-one-minute film almost illegible; some might argue that it is unwatchable. And this is not insignificant: the difficulty in deciphering and even watching Klier's film stems from the fact that, rather than a field of vision in which suspicion and performance are excessively visible phenomena, the CCTV images of Klier's film together generate an overarching invisibility that is entirely appropriate for understanding how surveillance works in the present-day West.

It is not clear how the images in Klier's film translate into the control of any person or object. Yet this lack of clarity does not mean control is not taking placerather, we learn from Klier's images that the control exercised by surveillance in the late-capitalist West is not of the visible, disciplining kind that the Panopticon enabled and that Foucault viewed as producing an inescapable totality of surveillance, complete with the self-policing of both watcher and watched. Instead, Klier's film evokes a number of theories that remain neglected in current scholarly approaches to surveillance but that offer more appropriate vocabularies for analyzing surveillance in late modernity than does the Panopticon, based as it is on an eighteenth-century model for penal architecture that was barely brought to realization.

Many readers will be familiar with Deleuze's short "Postscript on the Societies of Control.” This five-page-long comment piece presents itself as a 
departure from Foucault's descriptions of modern governmentality and the grip it exerts over its subjects. Deleuze writes in it: "Foucault has brilliantly analyzed the ideal project of these environments of enclosure, particularly visible within the factory: to concentrate; to distribute in space; to order in time" (3), but he proposes a development in which Western modernity has moved from the disciplinary "molds" of the past (the asylum, the prison) to become a much more fluid and un-navigable set of "modulations [...] like a self-deforming cast that will continuously change from one moment to the other, or like a sieve whose mesh will transmute from point to point" (4). These metaphors of a cast and a sieve, crucial to the "variable geometry" (4) that defines Deleuze's Control Society are compelling. However, they are not new; instead the phenomena they describe were already analyzed in the lectures Foucault was giving just two or three years after publishing Discipline and Punish. These were his Security, Territory, Population lectures at the Collège de France that are as rarely mentioned in cultural studies research as they are taught in humanities departments but that offer much-needed insight into the development of contemporary surveillance technologies and their effects on the subjects who currently live with them.

Foucault's lectures depart from his writing in Discipline and Punish on the inescapable regimes of eighteenth- and nineteenth-century Discipline, in order to deliver an account of the more flowing, but still control-oriented, systems of the twentieth-century West. These lectures on the development of a modern mode of governmentality, one that Foucault terms Security, trace the development of new power-models, evolved out of the orderly forms of Western power that he classified under the term Discipline in such studies as Madness and Civilization and Discipline and Punish. Crucially, later regimes of surveillance are characterized by a wider array 
of options for agency on the part of their subjects, or at least the sense that there are more options for acting in freedom. Thus, Foucault argues, while Sovereignty-the ancien-régime model of the early modern nation- “capitalized a territory” through the construction of concentric circles, their capital forming a literal centre of power where the sovereign resided (Security, Territory, Population 20), and while Discipline "structures a space" (20), producing grids and sectors of activity within a closed area defined by fixed relations of vision, Security opens up the borders of a space and implements looser structures than Sovereignty or Discipline, in order to ensure its futurity: "to plan a milieu in terms of events or series of events or possible elements" (1). In regimes of Security, power is invisible, and citizens can feel they enjoy a degree of freedom. Subtler than the illuminated physiognomies of Discipline's prisons, Security harbours the files of health records and passport information-and latterly, though they do not appear in Foucault's register of techniques, one might think of the archives of information harvested from individuals' internet use — all the while allowing its subjects in most cases to walk free.

Deleuze's brief and influential "Postscript" and Foucault's detailed lectures describe a late-modern power-model in which the subject and the community are not blocked or imprisoned but instead are co-opted as participants in an invisibly controlled flow of goods and subjects. Moreover, the flowing forms of Foucault's Security, and the self-transforming structures of Deleuze's Control Society, can be observed at work in surveillance documentaries by German filmmakers, including those ineffable images of Klier's Der Riese (Germany, 1983). Klier's CCTV images barely signify at all, so that it is hard to conceive of them as translating into clear instances of control over anyone or anything. And yet, as some of the very latest 
analysis of surveillance and control in contemporary Western societies suggests, the invisibility of power does not signify its absence. Zygmunt Bauman and David Lyon set out in Liquid Surveillance their vision of a "fluid and unsettling modernity," under the purview of which "all social forms melt faster than new ones can be cast" (Bauman and Lyon 2), and this includes the forms that surveillance takes in contemporary societies, becoming "much more flexible and mobile, seeping and spreading into many life areas in which once it had only marginal sway" (3). In Bauman and Lyon's liquid modernity, just like in Foucault's Security and Deleuze's Control Society, surveillance is happening and has very real effects on more areas of life than ever before. And these are the invidious Security techniques, seeping like the unset plaster of a cast or weaving like a mesh around unsuspecting subjects, that are at hand in the documentaries by Losmann and Farocki, as they engage with the power that states and corporations exercise over the subjects who live with them, not least through the work of surveillance.

\section{Hidden Panopticism in Farocki's Schöpfer der Einkaufswelten (2001)}

Harun Farocki died in Berlin in July 2014 after a virtuosic filmmaking career that began in the late 1960s, when he studied at the Deutsche Film und Fernsehakademie (German Film and Television Academy Berlin; dffb). Some of the most striking outcomes of his long and varied oeuvre are a late corpus of films set in the contemporary workplace, where subtle techniques of surveillance and coercion are to be found operating. When we think about surveillance in Farocki's oeuvre, the works that first come to mind might be the essay-films Arbeiter verlassen die Fabrik 
(1995) and Gefängnisbilder (2000), archival films that perform an archaeology of the recorded image as it has contributed to constructing, respectively, the end of the working day and the life of the prison inmate in Western modernity. Those are films that are interested in the production of the image by panoptic forms of surveillance, as they take in such iconically manipulative settings as the factory and the prison, among others. Yet in more recent works, and up until his death in 2014, Farocki and his collaborators developed a version of the American film mode of Direct Cinema, flyon-the-wall films that present footage without commentary, into which Farocki sometimes edited passages of found material, but always without scripting or voiceover. In these works, Farocki focused on the lives and experiences of two of the most pivotal subjects of late modernity, the worker and the shopping consumer, as they navigate the near-silent landscapes of post-Cold War capitalism, encountering in the process a mode of power that we can call, following Foucault, Security.

One of Farocki's earliest Direct Cinema works is the short but unforgettable Ein Bild (1983), whose eerie long shots observed a model being prepared and photographed for a pornographic image. The later Direct Cinema films are longer and more demanding on their viewers due to a combination of more abrupt cuts and quicker panning movements through unlabelled settings, with a focus on lives that are increasingly close to those of the average viewer watching in the cinema, at home or in the art gallery. That uncomfortable proximity, combined with the difficulty of navigating uncommented documentary footage, makes Farocki's Direct Cinema works incisive and challenging contributions to German cinema. One central aspect of the challenge of these works is their manner of showing that there is no place in the 
West, and no Western subject, entirely exempt from the techniques of observation and manipulation that are endogenous to surveillance in its late-modern forms.

The documentary of 2001, Schöpfer der Einkaufswelten, is exemplary of Farocki's uncommented Direct Cinema works. Its montage of footage was filmed in design and consultancy meetings, which together show West German and Austrian shopping malls in the planning stages from preconstruction to launch. Viewers see clips from staff training videos and advertising spots that are used in those design processes. This found footage is then interspersed with new images of saleswomen in training sessions and of architects and economists discussing how shoppers will move around the new malls and where their gaze will be drawn. There are clips from an annual convention in Las Vegas at which presentations are made on such topics as where the gaze of a customer will fall and, hence, how an ostensibly spontaneous purchase can be induced. Watching this montage, viewers learn that the contemporary mall is designed through a principle of pre-emption, so that the interior spaces of the most sophisticated malls are designed to guide shoppers using pointers and landmarks that appeal to the unconscious mind as it takes in optical data. The degree of preemption here is illustrated by the maxim cited in the film: "die Füßen gehen nur dorthin, wo die Augen schon waren"; in other words, if designers know the angle at which the eye will fall upon an advertisement, then adverts can be placed, and products-Waren - located, in the zone most conducive to productive shopping. Figure 2. From Harun Farocki dir. Schöpfer der Einkaufswelten (Germany, 2001). Image reproduced by kind permission of Harun Farocki Filmproduktion

Schöpfer der Einkaufswelten is a film about the hidden panopticism of the contemporary shopping centre. The latter's design principles are in line with the Panopticon of Foucault's analysis, generating as they do a "permanent visibility that 
assures the automatic functioning of power" (Discipline and Punish 201). Thus, Farocki does not neglect in his film to show CCTV images that take in the space of the mall, down every corridor and at every junction. He also makes sure to draw viewers' attention to the disciplinary training undergone by workers at the mall in order to secure their role in its surveillant hierarchy—-these figures are subjects of but also subjected to the surveillance that secures the smooth functioning of the mall. The film thus cites from Foucault's observations on the subjection of the warder to the Panopticon's system of surveillance, both through that training footage and indeed as Ingo Kratisch's camera sits as a watchful presence in meetings in which owners and designers of the shopping mall plan the entrapment of shoppers into more efficient consumerism. As viewers watch these long, closed sessions, they take on a surveillant role themselves, one sensitive both to the comedy and the horror that attach to these large-scale hidden manipulations.

Yet the manipulation and surveillance uncovered by Farocki, with the help of Kratisch's cinematography, also offer glimpses of a more sophisticated regime than that of the Panopticon. The mall's designers may know, and viewers of the film learn, that the shopper is in fact subject to a whole design process that has predicted how these events will take place and that has built the space with maximum profit as the goal. However, and crucially, the extreme visibility of the Panopticon is absent in the user experience of these shopping centre designs. Unlike the prisoner in Bentham's vision, the shopping consumer is likely to feel that she is moving around a space at her leisure, taking paths of her own choice and picking products from the shelves according to her own tastes. By revealing a knowledge that remains hidden from the shopping-centre consumer, the film makes the argument that, in the late-modern 
West, the high-visibility regime of Bentham's eighteenth-century Panopticon is being replaced by a model of surveillance that can be even more effective in securing power, thanks to its creeping invisibility.

\section{Success and Failure of Security/the Control Society: Farocki's Ein neues Produkt (2012) and Other Works}

Schöpfer der Einkaufswelten encourages its viewers to become more critical users of the shopping mall: that familiar environment that the film demonstrates is in fact the result of complex, and ultimately manipulative, design processes. A few years later, the short installation film of 2007, Deep Play, used footage of the projection of the 2006 FIFA World Cup in order to encourage a similar phenomenon of informed critique. The work's multiple screens showing player statistics, real-time 2D and 3D animation of the game, and CCTV from the football stadium demonstrate how the World Cup, a spectacle viewed by around 1.5 billion people in 2006, was invisibly but decisively observed in behind-the-scenes projections that turned the sport event into a controlled, thoroughly surveilled event marked by measurement and categorization. Yet others among Farocki's documentary works explore the limits of the high-control, high-surveillance environments of contemporary capitalism. For instance, Ein neues Produkt (2012) observes the design process of white-collar workplaces, settings in which surveillance and manipulation are not so successful as they were in the malls of Schöpfer der Einkaufswelten or on the screens that observed and categorized World Cup data in Deep Play. 
The design process undergone in Ein neues Produkt is aimed at an environment that, like the shopping mall or the World Cup game, functions in an ideal balance between control and movement. The players on the pitch, audience in the stadium, and shoppers in the mall should feel they are acting freely, while being observed by surveillance technology and quietly guided by the architectural designs hidden in their midst. In Ein neues Produkt, too, our focus is on the design of contemporary workplaces that guide their inhabitants while producing a sense of free movement and flexibility. Here, however, Farocki's eye is on the slippages of control, the procedures of the power-model that Michel Foucault termed Security, which, even as they situate the subject in a continuation of surveilled un-freedom, allow more space for movement than did the tight structures of the Panopticon. In Farocki's films, moreover, those spaces for slippage, inherent to the power-model of Security, seem to contain a potential for productive errors in the system to occur.

Ein neues Produkt observes the design processes of Hamburg-based management consultants Quickborner Team (QT). QT is a company known for its innovations in cybernetic interior design, an architectural style dating to the 1960s and considered liberal due to its central principle of adaptation to standard human movements (Rumpfhuber 46). Notwithstanding its liberal roots, QT is now consulted by multinational firms interested in the design of high-productivity workplaces. Thus, Farocki's film shows the Team designing leisure areas to keep employees at work longer and later, with coffee lounges and indoor balconies where, it is envisaged, employees will interact creatively for the profit of their employers. These soft workplace designs are the contemporary inheritors of the cybernetic spaces dreamt up in the 1960 s, with their flowing forms shaped to guarantee an employee "happiness" 
that leads ultimately to increased output. While profiling QT's designs for outside firms, the film also shows QT developing a set of incentives for their own, in-house employees. The CEO floats the idea that employees could be encouraged to pursue, in discussion with their employer, such personal projects as building a house or spending more time with spouses and children, and thereafter deliver progress reports on these personal projects at their annual performance appraisal. Kratisch's fly-on-the-wall camera documents a sinister kind of liberation here, one that sets the employee to work on personal tasks that, while they could in principle be fulfilling, will also become further objects for assessment, contributing to the capture of an even fuller surveillance-image of the individual within the workforce.

Given the consent of QT to be filmed in otherwise closed meetings, and the subsequent openness of their representatives to answering viewers' concerns at press conferences after the film was premiered, Ein neues Produkt can be said to reveal the softest and most humane kind of control at work. In this sense, the film is interacting with that "cast" that Deleuze envisioned deforming and re-forming itself around the human body in his "Postscript" (4). In the "Postscript," Deleuze theorized a model that is realized in QT's design process, of work environments in which control can look like support and in which a life dominated by work can resemble a life lived in freedom. The new footage presented in Ein neues Produkt, with its architectural models of open, user-friendly spaces, recalls the proposals made by Deleuze on the Control Society and the comments in Foucault's last lectures, in which he described the model of power/knowledge that he termed Security. Security is not constructed around prisons, although it uses them. Instead, Security is a model of power reliant on "the possibility of movement, change of place, and processes of circulation of both 
people and things" (Security, Territory, Population 48-49). The "mutations and transformations" (Security, Territory, Population 48) and high-mobility circulations that characterize this power-model make for a flexible environment in which control can resemble, paradoxically, conditions of subjective and structural freedom. It is not that these conditions are entirely undesirable. Indeed, David Lyon has commented on how the technologies that allow surveillance to happen are the same as those that allow for increased connection in the digital age. He writes, "My enjoyment of Skyping with distant children or grandchildren is a case in point" (Bauman and Lyon 83). In Security regimes, enjoyment is certainly an effect of technological developments. Indeed, what is most troubling about the newest surveillance techniques is their co-optation of enjoyment and hence the likelihood of our participation in the technical developments that at one and the same time ensure the ongoing possibility of control.

Ein neues Produkt explores the flowing, enjoyable topographic designs of neoliberalism such as Deleuze's brief essay on the Control Society and Foucault's more extensive series of lectures analyzed. Not only does Kratisch's camera move unimpeded around existing work spaces, Farocki's edit also samples animated footage of QT's design for Unilever's Hamburg office, in which workspaces will transmute unimpeded by walls into comfortable break lounges and conversation bars that offer a total view over the rest of the building. Certainly, these images suggest a postpanoptic — because uninterrupted by walls and corridors—flow of surveillant vision. The aspect of socialising, of making contact, in these new living-working spaces, evokes the enjoyable flow of the Security/Control regimes. Yet there is something in the visual narrative of Ein neues Produkt that does not consent to flow, 
an aspect of its montage that cannot assent to the norms of liquidity and enjoyable flexibility showcased in QT's design-process. The most memorable scene in Ein neues Produkt takes place in the second of its five short acts. Here, QT invites an external management consultant to inform its techniques of assessing employee performance. The visitor is a shamanic figure, making dramatic, at times pious hand gestures as he propounds the need for contemporary white-collar workers to "sich bilden," to work "aus eigenem Antrieb" and "bereit sein, [sich] zu öffnen." To the vocal dismay of the first audiences of this film, the consultant illustrates the latter claim via the metaphor of an oyster that, upon opening itself underwater, is penetrated by a grain of sand. Though irritating, this sand will be transformed in time into a precious pearl.

Figure 3. from Harun Farocki dir., Ein neues Produkt (Germany, 2012). Image reproduced by kind permission of Harun Farocki Filmproduktion

Writing in a dual-language volume sporting the dystopian title Schöne neue Arbeit/Brave New Work, Diedrich Diederichsen demonstrates how the consultant's oyster metaphor is permitted to stand in Farocki's film as a figure without "Hintergrund" (31), in other words. as a statement not bookended with the kinds of explanation-Begründung - that could perhaps make it sound less violently naive. For Diederichsen, this decision in Farocki's editorial process, to leave viewers looking in on a system of design ideas that do not connect up, has a kindness to it, and indeed Farocki did not set out to lampoon the businesspeople who welcomed him into their offices when other firms he approached did not. Yet, his editing insists on disconnection, it wields the technique of depicting a groundless figure, a statement without narrative syntax, and as an effect, Farocki casts an ultimately critical eye on the processes recorded here. The consultant's proposed modes of working are 
promoted, after all, not for the good of the employee who, as Diederichsen identifies, will, as an oyster, never have a stake in the profits generated by the pearl (39). Without needing to comment on what viewers are witnessing, Farocki's deft editing isolates such comments as that made by the management consultant. The film observes the process, and it selects images and statements to cut from it, as a result divorcing them from any broader discourse and following them with abrupt cuts and filmic silences that feel shocked, themselves, by what has been shown.

There is defamiliarization at work in Farocki's technique of cutting and combining Kratisch's footage and the sampled animations in this film. Ein neues Produkt screens discussions that will be well rehearsed by many of its viewers, about work-life balance, about exercising and spending time with loved ones in between work shifts. Yet at Farocki's cutting table, these familiar tropes of white-collar working life become the components of a dangerous farce, particularly in the scenes in which executives who are paid to design their employees' flexible working futures consider the kinds of personal reward, other than salary, that could be integrated into future employment contracts. As might well be expected, the film also shows the bosses' discussions being interrupted by objections from some of the employees who would risk being subject to such new considerations. Thus, the consultants' discussions of coworking spaces at the Vodafone headquarters is intercut with a statement by a worker who notes that he and his peers are more likely to fear the prospect of mobile workspaces, which reduce their privacy and disrupt work tasks, than to appreciate the liberation they supposedly bring.

The second interruption comes from a member of the QT consultancy itself, who begins to object to his bosses' idea of compensating workers not with higher 
wages but shorter working hours. However, this individual quickly realizes his error and hurries to reinsert himself into the excessively positive lexicon of the in-house discussion. There is a threat here of error in the system - even of system failure - $a$ threat that appears as QT is unsuccessful in signing the contract for collaboration with Unilever. This fact, not revealed in the film but instead in the written materials released alongside it, is nonetheless adumbrated by the film's tracking of a consultancy process taking place only at the executive level. By involving only executives, the process ignores precisely those administrative workers who would be subjected to an unsuitable hot-desking model that is, after all, fantasized for the idealized but rare "creative" roles available within multinational firms.

Ein neues Produkt is the culmination of a film oeuvre in which Farocki made visible the hidden processes of a contemporary West where corporations, states, and current technologies collaborate in making the lives of their subjects less and less free, while at the same time appearing to promote the enjoyment of those same subjects through the ostensible flexibilization of their everyday working world. Yet, this is also a film in which Farocki considers some of the productive potential of error in those processes, not least through the resistance of the very subjects who are most vulnerable to surveillance. This interest, in the potential internal system failure of regimes of surveillance that can seem impenetrable, was admittedly already present in other works by Farocki, for instance in his essay-film Gefängnisbilder, as part of which he rescreened CCTV footage of a prisoner being shot in prison in Corcoran, California. The footage seems to suggest a state/corporation system that is so powerful as to be able to end human lives, by means of a gun that is placed troublingly just beside the CCTV camera. Yet viewers of Gefängnisbilder are 
diverted by a voice-over in which Farocki states: "Die Ausübung der Macht muss immer wieder geübt werden." In other words, power is not impenetrable; indeed, it contains a degree of precarity that must be overcome again and again through renewed practices (and, simply, practice). In agreement with that comment in Gefängnisbilder, Ein neues Produkt highlights by its silent editing the techniques of repetition and rehearsal that underpin and undermine even the most invidious means of controlling the individual—including those that can appear the most ergonomic, in which the Western subject labours away in tightly designed spaces of controlled, or secured, comfort.

\section{Precarious Complicity with Security/the Control Society: Carmen Losmann's Work Hard Play Hard (2011)}

The models of Security that are tracked in Farocki's Ein neues Produkt, as hidden features of the "flexible" white-collar workplace, seem to enjoy more success in Carmen Losmann's German-language documentary Work Hard Play Hard (2011). At the same time, this is a film that underscores even more clearly the constitutive complicity underpinning the Control/Security regimes theorized by Deleuze and Foucault. Losmann has expressed profound respect for Farocki's documentaries of late-capitalist working cultures (Losmann in Cambridge, July 2015); indeed, her film has much in common with the remit of Ein neues Produkt, even to the point of including scenes filmed at the same firm as Farocki visited, Quickborner Team. Like Farocki, Losmann sets out to reveal the very latest techniques of personnel management used in white-collar workplaces in Germany, techniques that are 
perceived as flexible while contributing to the recovery of company profits after the Global Economic Crisis. Even more so than in Farocki's film, however, Losmann unveils a troubling side-effect of the invisibility and apparent "flexibility" of systems of Security/Control. This side-effect takes the form of the self-destructive, perverse participation — in short, the complicity — of the surveilled individual in her or his unfreedom.

Work Hard Play Hard features new footage filmed in consultancy meetings between the firm Behnisch Architekten and QT consultants, who together are designing the new Unilever headquarters in Hamburg. It also shows images of the offices where the interior-architectural model of Desksharing has been implemented at the Kronberg campus of the firm Accenture. Losmann's camera is quietly mobile in these working spaces, its panning evoking a postpanoptic creep of surveillance, in which employees appear on what looks like a conveyor belt of human products. This is particularly the case when the camera glides past a white desk at Unilever Hamburg, at which secretaries sit who are at first only visible as decapitated heads. It is a few moments before the camera takes in the other side of the desk and viewers can watch the reality of hot-desking, in which colleagues must shift between a limited number of computers in order to make space for one another to work. The film then goes on to screen a series of alternating scenes from an assessment centre where the firm Schott Solar is carrying out an audit of employee behaviours and skills and an outdoor leadership training session in the Lüneburger Heide. Finally, a long coda features scene after scene filmed in the offices of business consultants Towers Watson, Kienbaum, Change Agents, and Endress+Hauser. The surveillance techniques that are being designed and carried out in these contemporary business 
settings are far from those of the Panopticon, where the body of the prisoner is held in confinement, always aware of its vulnerability to being seen and, hence, always selfpolicing. Some of the planning processes are unseen by most employees, but many more are reliant upon the consent and indeed the enjoyable participation of the workers whom they affect.

Figure 4. CCTV footage from leadership training course in Carmen Losmann dir. Work Hard Play Hard (Germany, 2011). Image reproduced by kind permission of the filmmaker

For instance, the leadership trainees in the Lüneburger Heide are shown coauthoring a set of guidelines for their own behaviour in the workplace, including the instructions: "Anweisungen werden nicht blind übernommen" and "jeder verhält sich souverän." These are instructions for a secure, self-possessed behaviour that take on horrible irony when edited to appear between scenes of planned manipulation in the upper echelons of the workplaces in question, in relation to which employees are anything but sovereign. In the guidelines scene, Losmann gives her viewers access to the workings of a Security society that functions by trading apparent flexibility for the white-collar workers' consent. Thus, at the assessment centre, the consultant who is there to gather "ein vollständiges Bild" of Schott Solar employees meets with a woman who exerts herself visibly during her assessment and describes her hope of showing "ein solides Bild" in her professional life. This employee is clearly striving to be the kind of subject that the assessment operation requires. However, while Losmann's film is interested in that phenomenon of striving, self-destructive complicity in an ever-more demanding workplace, Work Hard Play Hard also shows a first obstacle to such complicity, namely its precarity, its predestination to failure.

Talking about her film in 2015, Losmann claimed that this employee who strives to give a good impression at her assessment interview wishes to convey "eine 
souveräne Persönlichkeit” (Losmann in Cambridge, July 2015). In a perverse tautology of performed subjectivity, she wishes to be perceived as being the subject she is meant to be and above all to demonstrate that successful working identity during the assessment process. Whether such a performance of successful working identity could ever be pulled off is called into question, however, as the same employee fluffs her assessment through recurrent nervous laughter. This laugh is distinctly unenjoyable; indeed it repeatedly disrupts the interviewing process, setting both interviewers and Losmann's viewers on edge. Finally, the laugh forms the focus of highly personal criticism of the employee at the end of her assessment. Even more troubling than this performance of uncomfortable complicity, however, is the appearance in the assessment centre footage of a high-performing male employee whose answers are slickly rehearsed in order to please his bosses. The visiting consultant identifies certain problems with this employee's performance, but she concludes with an overall good assessment. However, viewers may notice his right hand, which balls itself involuntarily into a fist while his left hand holds it down in a gesture of unconscious self-pacification.

Figure 5. Employee at the assessment centre in Carmen Losmann dir. Work Hard Play Hard (Germany, 2011). Image reproduced by kind permission of the filmmaker

Schott Solar has commissioned the assessment process in order to improve working procedures, to ensure that company employees are behaving in ways that are harmonious and efficient. Yet these employees are shown by Losmann's cinematography as being at once compliant, yet at the same time unwittingly resisting the process. These individuals cannot ever be the ideal employee with all the characteristics the firm requires. In this sense, even as Losmann's film depicts some of the most disturbing developments of the Control/Security Society, she also chanced 
upon a resistance that can emerge even when the subject of surveillance seems, perversely, to be following that model as carefully as she or he can.

\section{Complicity as Resistant Response to Surveillance}

In Work Hard Play Hard and in Farocki's Ein neues Produkt, the surveilled subject does not fit with the image sought by the training and design processes of the contemporary white-collar workplace. Yet what is disturbing in those works is the way in which that subject really tries, against all odds, to comply with what is required of her or him. The employees in the scenes shot at the assessment centre in Work Hard Play Hard are — in keeping with the film's title_-working as hard as they can to comply with what is expected of them. When these workers are criticized in follow-up sessions and presented with the behaviours they must learn to display, that work of complicity continues, and the employees make commitments to change their

performance in future. Meanwhile, the worker in Ein neues Produkt who objects to a reduction in working hours (and hence compensation) quickly reinserts himself into the consenting group when he realizes his objections are meeting with none of the flexibility his bosses require of him.

However, while that willingness on the part of the workers in Farocki's and Losmann's films may signal that there is little hope of resistance to the new and sophisticated techniques of surveillance in today's white-collar workplaces, there is nonetheless an element of resistance operating here. That element exists in the form of those behaviours that appear to be complicit in the undoing of the subject's freedom but that, precisely through the attitude of complicity, are able to perform a 
parodic critique of systems that would otherwise be difficult to resist. Counterintuitive as it may seem, it is here, in their tracking of a submission to surveillance, that these documentaries become so exciting as examples of a new critical film mode. To understand the excitement that attaches to these works, in which resistance seems to be depicted as failing — works that therefore should not provoke hope at all—we will need to return to the post-Freudian theory of perversion, as developed by Jacques Lacan and later Slavoj Žižek. In Lacan's revisiting of Freud's psychopathology, perversion is defined by the actions of a subject who makes him- or herself "the instrument of the Other" (320). The pervert fulfils a desire perceived as issuing from an authority figure: in the subcategory of sadism the Other's violent law is made to apply to others, and in masochism, its force is turned against the self.

Tellingly for my reading of these recent German documentaries, in Žižek’s clarification, perverts are not abnormal deviants (sadists or masochists to society's more vanilla participants) but in fact the most loyal followers of the law. Žižek writes of the pervert: "this 'transgressor' par excellence who purports to violate all the rules of 'normal', decent behaviour, effectively longs for the very rule of Law" ("Is it Possible to Traverse the Fantasy in Cyberspace?" 117-18). Far from a lawless criminal or a pathological patient, Žižek's pervert is the subject who most respects, nay enjoys, the commandments directed at him or her. Perverts are the law-keepers, the gatekeepers, bureaucrats, and ticket-control officers who ensure the continued functioning of the law, however absurd or unjust its content, and however harmful it may prove, ultimately, to their own subjectivity. Yet there is also a subversive potential in Žižek's account of the pervert, who causes disarray by practising a "tooliteral identification" with the law (The Plague of Fantasies 14), taking literally the 
commandments she or he receives and acting them out to the limit of possibility. In effect, the pervert enjoys the law too much: by following the law at its word, she is able to subvert that law, carrying out even its most senseless and self-defeating tenets to the point that they appear untenable and thus lose their seductive, complicityinducing power.

It is admittedly disturbing when, in Work Hard Play Hard, Losmann shows the employees of contemporary firms enjoying their obligatory self-improvement activities. Yet this, too, is the mark of a perverse performance that contains the potential for resistance to systems of surveillance. We may shudder when Schott Solar's young managers express enjoyment of the same jobs that are on the line as they falter and fail in the assessment centre. Here, enjoyment is expressed not so much in the laughter of the employee whose nervousness leads to harsh criticism, but instead in the eagerness of her young male colleague who comes out well from the process, the one who is seen trying hardest to impress those who will decide his future employability. These processes are painful to watch, but there is value in watching them under Losmann's and Farocki's guidance, as directors who are able to show up the impenetrability of a surveillance system that has special urgency in the case of working models that appear to be flexible and freeing but that in fact penetrate the life of the individual much more deeply than a CCTV camera ever could. This is because, crucially, the comic literalness with which the figures in their documentaries are shown carrying out their instructions makes for a resistant performance that is admirably light of touch as it uncovers invisible processes of surveillance that nobody watching their works can escape, no matter what they do. 
Of course, it is not guaranteed that perversion will always be subversive. The overstated performances of the real-life workers shown cooperating in these films are genuine events, and many viewers would hope they will be successful for those carrying out the performance. After all, these individuals are cooperating with being assessed and surveilled in order to secure their livelihoods. The deciding factor here, in whether a perverse performance can have a resistant element, is the presence of the documentarist's camera. Ironically, considering the qualities of surveillance associated with any camera, it is the filming camera of the documentarist that makes the employees' counterintuitive complicity with surveillance resistant. Another factor that remains tricky here is that the employees themselves do not necessarily consent to their performances being shown in that way, as perversely subversive. In her talk in 2015, Losmann revealed that the employees filmed performing so enthusiastically at the assessment centre were horrified when they saw the documentary's final edit for the first time in the cinema, a moment at which their complicity in a sinister mode of surveillance became more visible than it was in the closed context of their workplaces (Losmann in Cambridge, July 2015). It would be too much to ask that the workers would lampoon their own situation and thus risk their livelihood. Instead, it seems to remain the role of the critical documentarist to take the mere perversity of the contemporary worker's self-subjection and turn it into something more, into a perversion that could yet be revolutionary.

The final third of Work Hard Play Hard is an excellent example of that transformation of an Orwellian scenario, via critical filmmaking, into something that looks much more resistant. Losmann made the editing decision in the final section of her film simply to play one scenario of training for increased profitability after 
another. While this decision makes the third act of an already challenging film almost impossible to watch, it nonetheless enables Losmann to stress to the point of overstatement the invidiousness of the techniques her film is tracking. Because it is deliberately_-perversely? — overstated, this coda of too many images is appropriate precisely due to its excess, its repetition ad nauseam of the pervasiveness of surveillance in those white-collar workplaces that are designed to be flexible, progressive, and creative.

\section{Conclusion}

The contemporary workplace documentaries discussed in this article offer a glimpse at what a critical cinema can look like in an age of seemingly inescapable surveillance. There is much at stake here, including the success or the failure of film projects that set out to be resistant and in so doing must stray into territories in which the most invidious techniques of control are active. ${ }^{4}$ To watch these quiet and troubling films by Farocki and Losmann is to become aware at once of the difficulty of existing outside of the modern workspaces in which human behaviour has been preplanned, predicted, and manipulated, in most cases without the subjects of that planning even so much as noticing. And yet, to watch them is at the same time to awaken to the likelihood that the subject of surveillance will nonetheless find some way of resisting surveillance, even if she appears at times to be enacting a perverse and self-destructive participation — an enjoyable complicity —in the techniques of control that haunt her everyday movements.

Figure 6. from Harun Farocki dir. Der Ärger mit den Bildern (Germany, 1973). Image reproduced by kind permission of Harun Farocki Filmproduktion 
I have argued that the experimental forms of documentary that Losmann and Farocki elect to employ allow them to express an effective critique. Their critical modes of filmmaking are effective, I contend, because these are filmmakers urgently aware of the conditions of film's production, conditions that do not rule out a certain complicity on the part of film itself with technologies that manipulate and co-opt those who are watching — and that therefore risk becoming complicit with systems of visual control and totalization even as they aim to critique them. For instance, the embarrassment of the employees filmed by Losmann, at seeing on screen her presentation of their role in an assessment process whose techniques she condemns, shows some of the risks attendant on documentary, as it intervenes in lives that will always be more complex than the moving image can show. However, it is my view that both Losmann and Farocki ultimately succeed in repurposing technologies that have been used to record and manipulate their subjects, and in this way, they have produced examples of a genuinely critical filmmaking that makes available the possibility for the counter-surveillance of those systems.

By repurposing moving-image technology for critical purposes, these countersurveillant films express a counterintuitive kind of hope, in the first instance through their critical citation of the surveillance technology that gets close enough to its subjects to make visible certain of the possibilities for errantry and eruption lurking within the manipulative systems that can seem so omnipotent in present-day capitalism. The contemporary workplaces visited in these films rely on methods of surveillance that are meant to hold their participating subjects down in procedures of observation, assessment, and manipulation. These are procedures designed, moreover, to be enjoyed by those who are complicit in them. However, the documentarists' 
depiction of those methods reveals them as vulnerable to the threat of failure. This is because their films force us to observe as certain of the workers who populate the workplaces in question refuse to cooperate, and as others cooperate in perverse fashions that, even when they are genuinely intended, cannot help but perform the hidden instabilities of environments designed to secure control.

It has been important in my analysis to show how, in these films, surveillance is not limited to the classic filmic scene of the observation of a victim by a camera. Nor is surveillance necessarily something that is being "done" by a guard or warder or spy. Instead, I have argued that these works evoke and build upon a theory that Foucault proposed in his final years at the Collège de France and that tends to be neglected in research and teaching on surveillance but which is more helpful than the outdated model of the Panopticon for conceiving both what surveillance is in the present day and the kinds of response that are available for overturning systems of control against which resistance can otherwise seem so futile. Replacing the centralized power-model of absolutist Sovereignty and the hard structures of eighteenth- and nineteenth-century Discipline, Security is formed under late twentieth-century liberalism's softer touch. Topographically, it operates by opening up the borders of a space and implementing looser structures than the Discipline model represented by the Panopticon. Put in a contemporary idiom, in Foucault's model of Security, the Panopticon becomes a network and is thus rendered more fluid and flexible.

Such a development may be viewed as not entirely undesirable. After all, the designs being developed by the business consultants and shopping centre architects in these films were first dreamt up in the hope of leading to more balanced, humane 
work settings, honed to the enjoyment of their users, in keeping with the cybernetic designs with which QT began in the 1960s. Yet, as the films by Farocki and Losmann demonstrate, those techniques have been co-opted for much more invidious developments, in which the surveilled subject becomes a complicit, enjoying consumer of technologies of Security/Control. That revelation of complicity is the contribution these films make to understanding why the liberal-control regimes described by Foucault in his late lectures are able to succeed — and how they may fail. Certainly, the complicity of the surveilled subjects in these works makes the prospect of halting surveillance in the future, or transforming it for more progressive or collective use, difficult to imagine. On the other hand, though the systems of surveillance and complicity shown in these films cannot be stopped, their directors have found cinematic means of documenting a critical content that inhabits those very systems. This is the content revealed by Losmann's editing, her conveyor belts of subjects, the drone-like swooping of her camera around haunted office spaces overlaid with voice-overs of executives maniacally describing the benefits of these futuristic workplaces for the utterly unfree. It is also what emerges from the sharp syntax of Farocki's edits, his cuts and pauses that, for me, rehearse the gaps in an otherwise smooth system of surveillance, gaps in which there might after all be some space for resistance.

\section{Notes}

1 There are, of course, notable exceptions: Farocki held in high esteem Alexander Kluge, whose films Der starke Ferdinand (1976), Die Patriotin (1979), and others defy norms of dramatic plot and form, and he collaborated in the feature films of one-time student Christian Petzold, which resist the problematically satisfying closure provided by fully comprehensible plots. 
2 In my book, After the Stasi, I differentiate between the conscious and interactive collaboration of Stasi informants and the kinds of isolated and unaccounted-for complicity that define the everyday processes of late capitalism (Ring 16, 199-226, 238-39).

3 This supposedly progressive prison, completed in 1829, was characterized by the use of solitary confinement intended to enforce self-reflection on the part of prisoners. A traumatised Dickens visited in 1842 and wrote of the prison that he could never been happy so long as he was "consenting to it in the least degree" (Dickens 112).

4 Movingly, Carmen Losmann admitted that, when making Work Hard Play Hard, she even found herself, too, performing the role of the creative worker keen to be as effective and productive as possible (Losmann in Cambridge, July 2015).

\section{Works Cited}

<bok>Bauman, Zygmunt, and David Lyon. Liquid Surveillance. Cambridge: Polity, 2013.</bok>

<other>Deleuze, Gilles. "Postscript on the Societies of Control." October 59 (1992): 3-7.</other>

<bok>Dickens, Charles. American Notes: For General Circulation. London: Penguin, 2000.</bok>

<bok>Farocki, Harun. dir. Der Ärger mit den Bildern: Eine Telekritik von Harun Farocki. Germany,

1973.</bok>

<bok>—_. Arbeiter verlassen die Fabrik. Germany, 1995.</bok>

$<$ bok>—. Gefängnisbilder. Germany, 2000.</bok>

<bok>—. Schöpfer der Einkaufswelten. Germany, 2001.</bok>

<bok>—. Deep Play. Germany, 2007.</bok>

<bok>—. Ein neues Produkt. Germany, 2012.</bok>

<bok>Foucault, Michel. Discipline and Punish: The Birth of the Prison. London: Penguin,

1991.</bok> 
Journal: SEMINAR; Volume 52; Issue: 4

DOI: $10.3138 /$ SEM

<edb>Foucault, Michel. Power/Knowledge: Selected Interviews and Other Writings 1972-1977 by

Michel Foucault. Trans. Colin Gordon. HarClow: Harvester, 1980.</edb>

<edb>Foucault, Michel. Security, Territory, Population: Lectures at the Collège de France. Ed. Michel

Senellart, trans. Graham Burchell. Basingstoke: Palgrave Macmillan, 2007.</edb>

<bok>von Donnersmarck, Henckel. Florian, dir. Germany: Das Leben der Anderen, 2007.</bok>

<bok>Hochhäusler, Christoph. dir. Eine Minute Dunkel. Germany, 2011.</bok>

<bok>Klier, Michael. dir. Der Riese. Germany, 1983.</bok>

<edb>Lacan, Jacques. "The Subversion of the Subject and the Dialectic of Desire in the Freudian

Unconscious," Écrits. Ed. Malcolm Bowie, trans. Alan Sheridan. London: Routledge, 1997.

292-325. $</$ edb $>$

<bok>Losmann, Carmen. dir. Work Hard Play Hard. Germany, 2011.</bok>

<conf>Losmann, Carmen. Talk at the conference "Screening Work" at University of Cambridge, 9

July $2015 .</$ conf $>$

<bok>Petzold, Christian. dir. with Harun Farocki, Barbara. Germany, 2012.</bok>

<jrn>Rentschler, Eric. “The Surveillance Camera's Quarry in Hochhäusler's Eine Minute Dunkel."

German Studies Review 36.3 (2013): 635-42.

<http://dx.doi.org/10.1353/gsr.2013.0111>.</jrn>

$<$ bok>Ring, Annie. After the Stasi: Collaboration and the Struggle for Sovereign Subjectivity in the

Writing of German Unification. London: Bloomsbury, 2015.</bok>

<edb>Rumpfhuber, Andreas. “Arbeitsplatzsymptome: Anmerkungen zum Design zeitgenössischer

Arbeitsplätze." Schöne neue Arbeit: Ein Reader zu Harun Farockis Film Ein neues Produkt.

Ed. Nina Möntmann. Hamburg: Walther König, 2014. 41-53.</edb> 
Journal: SEMINAR; Volume 52; Issue: 4

DOI: $10.3138 / \mathrm{SEM}$

<bok>Trojanow, Ilija, and Juli Zeh. Angriff auf die Freiheit: Sicherheitswahn, Überwachungsstaat und

der Abbau bürgerlicher Rechte. Munich: Hanser, 2009.</bok>

<edb>Žižek, Slavoj. “Is it Possible to Traverse the Fantasy in Cyberspace?” The Žižek Reader. Ed.

Elizabeth and Edmond Wright. Oxford: Blackwell, 1999. 102-24.</edb>

<bok>Žižek, Slavoj. The Plague of Fantasies. London: Verso, 2007.</bok> 